The Open Microbiology Journal
CrossMark
Content list available at: www.benthamopen.com/TOMICROJ/
DOI: $10.2174 / 1874285801610010078$

\title{
Molecular Diagnostic Methods for Detection and Characterization of Human Noroviruses
}

\author{
Haifeng Chen ${ }^{1, *}$ and Yuan $\mathrm{Hu}^{2}$ \\ ${ }^{I}$ Division of Molecular Biology, Office of Applied Research and Safety Assessment, Center for Food Safety and Applied \\ Nutrition, U.S. Food and Drug Administration, Laurel, MD, USA \\ ${ }^{2}$ Northeast Region Laboratory, Office of Regulatory Affairs, U.S. Food and Drug Administration, Jamaica, NY, USA
}

\begin{abstract}
Human noroviruses are a group of viral agents that afflict people of all age groups. The viruses are now recognized as the most common causative agent of nonbacterial acute gastroenteritis and foodborne viral illness worldwide. However, they have been considered to play insignificant roles in the disease burden of acute gastroenteritis for the past decades until the recent advent of new and more sensitive molecular diagnostic methods. The availability and application of the molecular diagnostic methods have led to enhanced detection of noroviruses in clinical, food and environmental samples, significantly increasing the recognition of noroviruses as an etiologic agent of epidemic and sporadic acute gastroenteritis. This article aims to summarize recent efforts made for the development of molecular methods for the detection and characterization of human noroviruses.
\end{abstract}

Keywords: Acute gastroenteritis, etiologic agent, human noroviruses, molecular diagnostic methods.

\section{INTRODUCTION}

Human noroviruses are a group of highly related viruses that were first identified from fecal specimens obtained in 1968 during the investigation of an outbreak of acute gastroenteritis in Norwalk, Ohio. The prototype strain designated as Norwalk virus was discovered by Kapikian and colleagues in 1972 [1]. Viruslike particles of 27-nm in size were visualized from Norwalk-derived patient's fecal filtrate using electron microscopy (EM). The viruses are now recognized as the most common cause of epidemics of acute gastroenteritis and an important cause of sporadic gastroenteritis in both children and adults [2]. The incidence of norovirus illness is high. Annually, human noroviruses account for over 267 million infections worldwide [3]. In developing countries, it is estimated that over 1 million hospitalizations and 220,000 deaths occur among children less than 5 years old each year [4]. In some industrial countries including United States where childhood immunization has substantially reduced the incidence of rotavirusassociated gastroenteritis [5], noroviruses become the leading causative agent of acute pediatric gastroenteritis [6]. A major impediment to the diagnosis of norovirus infection is the absence of an effective cell culture system or small animal models for propagating the viruses. Owning to the exceptionally low infectious dose, a few virus particles can initiate a norovirus infection. Conventional detection methods e.g. electron microscopy and immunoassays apparently lack sufficient sensitivity. In the absence of simple and sensitive detection approaches, the etiologic role of noroviruses in the sporadic and outbreak-associated acute gastroenteritis has been immensely underestimated. Conventional diagnostic methods left $62 \%$ to $94 \%$ of cases in the diagnostic void [7 - 8]. This diagnostic gap has not been reduced until new and more sensitive molecular detection methods have been introduced in the field since the1990s. Since then, a wide variety of molecular methods have been developed and exploited for the detection of noroviruses in clinical, food and environmental samples. This review aims to summarize recent efforts made for the development of molecular methods for the detection and characterization of noroviruses, an agent of acute viral gastroenteritis.

\footnotetext{
* Address correspondence to this author at the Division of Molecular Biology, Office of Applied Research and Safety Assessment, Center for Food Safety and Applied Nutrition, U.S. Food and Drug Administration, 8301 Muirkirk Rd, Laurel, MD 20708, USA; E-mail: haifeng.chen@fda.hhs.gov
} 


\section{GENOME ORGANIZATION AND CLASSIFICATION}

Noroviruses are a group of highly related and extremely infectious, small round-structured, nonenverloped viruses with a positive-sense single-stranded RNA genome of approximately $7.6 \mathrm{~kb}$ in length. The viral RNA is covalently bonded to the viral protein genome (VPg) at the 5'end and contains a polyadenlated -A tail at the 3'end. The genomic viral RNA codes for three open reading frames (ORFs), designated ORF1, ORF2, and ORF3 (Fig. 1). ORF1 is translated as a 194-kDa polyprotein that is cleaved by the virus cysteine protease into 6 nonstructural proteins including p48, nucleoside triphosphatase (NTPase), p22, VPg, Protease (Pro) and RNA-dependent RNA polymerase (Pol). ORF2 encodes a 60-kDa major viral capsid protein (VP1), a structural protein involving virus replication. ORF3 encodes a 23$\mathrm{kDa}$ structural minor capsid protein (VP2) interacting with the viral RNA when the virion formation occurs [9].

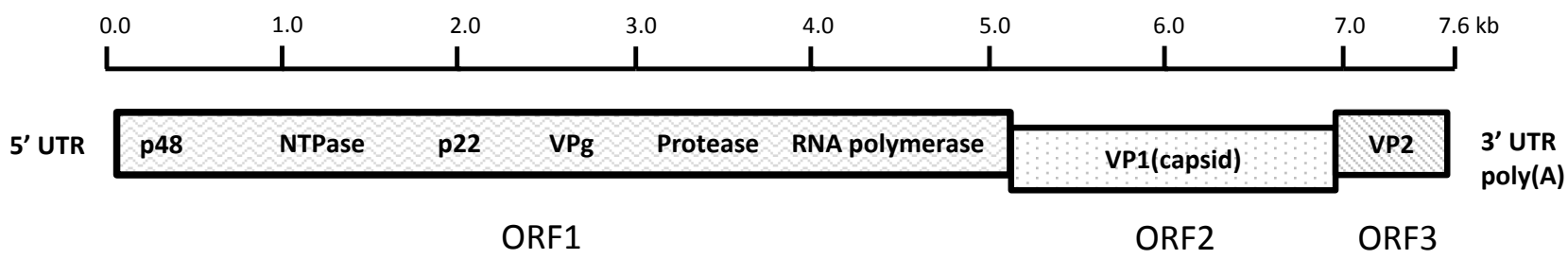

Fig. (1). Schematic of human norovirus genome organization. The viral genome is composed of a single-stranded, positive-sense $\mathrm{RNA}, \sim 7.6 \mathrm{~kb}$ in length and is divided into three open reading frames (ORFs) designated ORF1, ORF2, and ORF3. ORF1 encodes 6 nonstructural (NS) proteins including an NTPase, 3C-like protease, and RNA-dependent RNA polymerase (Pol). ORF2 and ORF3 encode major structural capsid protein 1 (VP1) and minor capsid protein 2 (VP2), respectively. Nucleotide position numbering refers to the Norwalk virus genomic sequence (GenBank accession no. NC001959).

Noroviruses belong to highly antigenically and genetically diverse genus Norovirus in the family Caliciviridae, which also includes Sapovirus, Lagovirus, and Vesivurs as well as Nebovirus [10]. Historically, antigenic classification of noroviruses was determined on the basis of cross-challenge studies in volunteers and cross reactivity analysis by solid-phase IEM [1, 11 - 13]. These studies demonstrated that considerable antigenic diversity among norovirus strains has been observed. However, due to the cross-reactivity of the antibodies, the antigenic classification schemes displayed limited accuracy and reproducibility [14]. It is thought that these limitations were mainly linked to the cross-reactive antibody responses observed in individuals $[15,16]$.

Because of the absence of in vitro cell culture system for the replication of human noroviruses, direct serotyping of the viruses using a conventional neutralization test has been severely hampered [17]. Genetic classification of the viruses was defined only from 1990 after the successful cloning of the Norwalk virus genome [18]. Since then, genomic sequencing of the amplicon derived from reverse transcription polymerase chain reaction (RT-PCR) and subsequent phylogenetic analysis have become the principle means for characterizing the viruses and understanding the genetic relatedness of virus strains $[18,19,14]$. Based on the complete sequence of capsid protein, noroviruses are genetically classified into at least 5 genogroups (GI-GV) [20], with viruses within genogroup I, II, and IV associated with human gastroenteritis. Genogroup III and V have been identified in cows and mice, respectively. Virus variants consisting of canine norovirus were recently discovered [21, 22]. GI and GII contain the majority of norovirus strains and present the greatest genetic diversity. They can be further classified into around 31 genotypes, with 9 genotypes in GI and 22 in GII, respectively [20, 23]. Prototype Norwalk virus was assigned as genogroup I, genotype 1 (GI.1). The presence of the extensive variability of norovirus strains is resulted from both accumulation of point mutations related to errorprone RNA replication and recombination between related viruses [24, 25]. Of all the human norovirus strains, GII.4 has become the predominant strains causing the most outbreaks and sporadic gastrointestinal disease in the United States and worldwide despite the great diversity of noroviruses [2, 26].

\section{TRANSMISSION OF NOROVIRUSES AND THEIR GENOTYPES}

Noroviruses are recognized the cause of person-to-person transmission of acute gastroenteritis in a broad breadth of healthcare settings e.g. hospitals, nursing homes, and community settings e.g. schools, day-care centers, cruise ships, and restaurants. Transmission most often occurs via the fecal-oral route, by person-to-person contact, by consuming foods contaminated at the source through environmental contamination or prepared by infected food handlers, by exposure to aerosolization of the virus and subsequent contamination of surfaces. Of all, person-to-person contact is the most common route, accounting for $83.7 \%$ of all reported outbreaks in the United States from 2009 to 2013 while foodborne transmission was $16.1 \%$ [27]. GII.4 was considered to be more frequently associated with person-to-person 
transmission while GII.12 and GI.7 were likely associated with foodborne illness [27]. Globally, approximately 14\% of all norovirus outbreaks are attributed to food with $37 \%$ of outbreaks caused by mixtures of GII. 4 and other viruses, $10 \%$ by GII.4, and $27 \%$ by all other single genotypes [28].

\section{MOLECULAR DIAGNOSTIC TESTS}

Electron microscopy (EM) was initially utilized for direct detecting norovirus particles with $27 \mathrm{~nm}$ in diameter from fecal specimens. However, it is not a high throughput assay that can be practically deployed in epidemiological or clinical studies because of insufficiently distinctive surface morphology of the viruses, and low assay sensitivity ( $10^{6-7}$ virus particles per gram stool) as well as requirement for costly instrument and well trained microscopist [29]. Immunoassay-based detection represents a substantial advance for norovirus diagnostics. However, norovirus immunoassay testing has demonstrated poor sensitivity when applied on clinical specimens [30]. Due to the lack of rapid and sensitive tests, considerable amounts of outbreaks of nonbacterial gastroenteritis went undected and were mistakenly thought to have unknown etiologic agent. Noroviruses have been considered to play an insignificant role in sporadic and outbreak-associated acute gastroenteritis [7, 31]. The successful cloning and sequencing of Norwalk and Southampton agents led to breakthrough in understanding the molecular biology of noroviruses and paved the path to the development of more molecular-oriented detection methods [18, 32]. The availability and application of more sensitive molecular approaches has rapidly changed our understanding of norovirus disease. Fig. (2) depicts some of the noteworthy changes in the detection of human noroviruses since 1972. The introduction of RT-PCR in 1992 marked the beginning of molecular diagnostics of noroviruses [33].

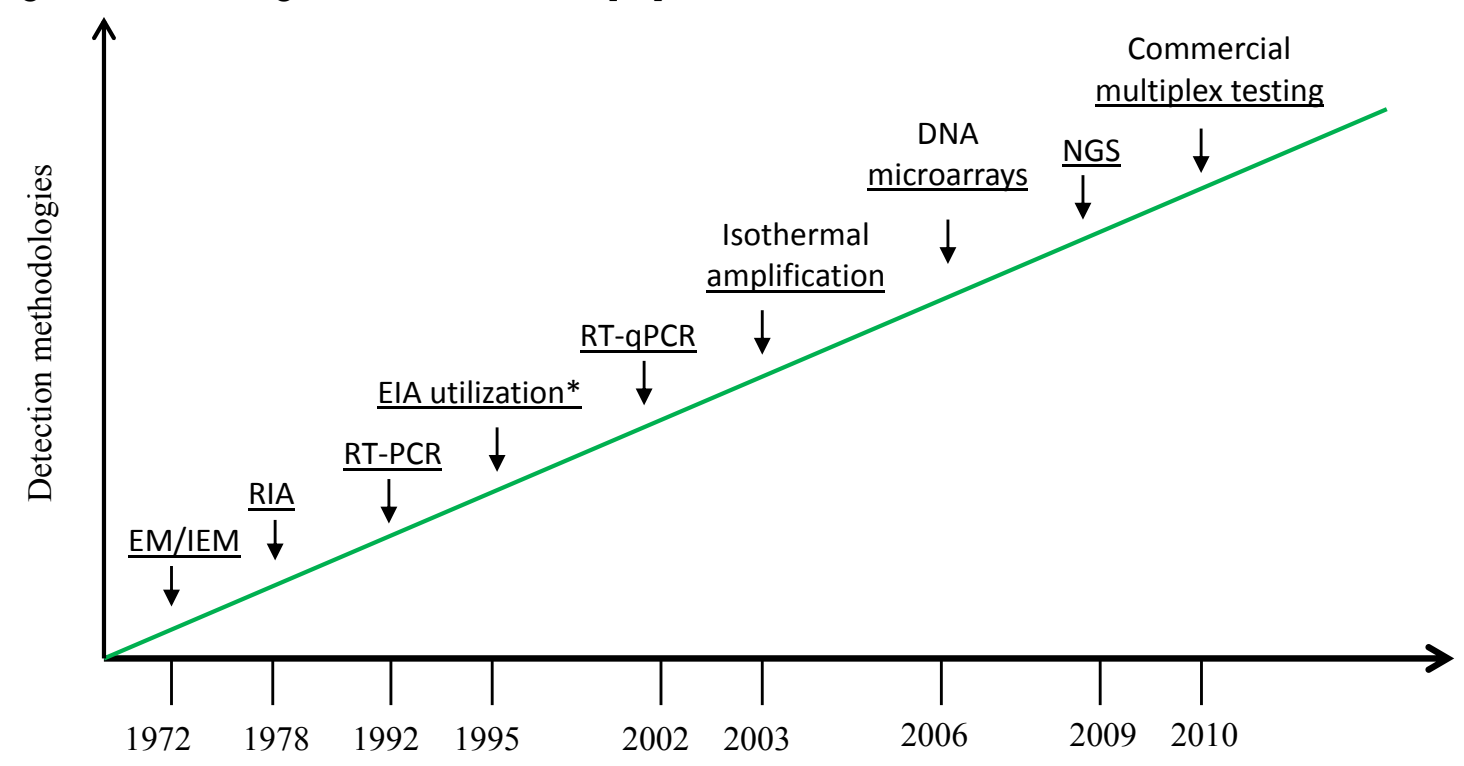

Fig. (2). Advances in detection of human noroviruses since 1972.

EM/IEM: electron microscopy/immune EM, RIA: radioimmunoassay, EIA: enzyme immunoassay, RT-qPCR: real-time quantitative reverse transcription polymerase chain reaction, NGS: next-generation sequencing

*EIA for antigen detection

\subsection{Detection - Monoplex Reverse Transcription RT-PCR and Isothermal Amplification}

\subsubsection{Standard RT-PCR}

Viral RNA extracted from clinical samples e.g. stools, vomitus and serum is transcribed to complementary DNA (cDNA) in the presence of reverse transcriptase using either random primers or norovirus specific primers. The resulting cDNA then can be amplified by DNA polymerase using norovirus specific primers. Primer design plays a critical role in the sensitivity and specificity of RT-PCR assays. The selection of inappropriate primers may result in false-negative consequence, making the diagnosis void. Given the genetic diversity of noroviruses, regions within the viral genome with the highest degree of conservation among strains are targeted for primer selection for RT-PCR amplification. Early conventional RT-PCR assays utilized a number of primers mainly selected from the highly conserved RNA polymerase region in ORF1of the prototype Norwalk virus genome [33 - 37]. Many of the assays 
employing the primers resulted in an unexpectedly low detection rate of EM-positive clinical specimens owing to the wild genetic diversity among virus strains. In order to resolve this diagnostic problem, a number of efforts have been made to design broadly reactive primers for the RT-PCR assays with the availability of accumulating sequence information of noroviruses strains [38 - 41]. The new design of the primers in the studies was still primarily based on the RNA polymerase region, but they significantly improved the assay sensitivity and specificity via southern hybridizations and DNA sequencing.

Although the polymerase region has been favored to amplify noroviruses, the great genetic diversity of the viruses has still made it difficult to detect all the strains using the primers chosen from the region. It was reported that viruses within the same genogroup displayed only $60.8 \%-63.3 \%$ nucleotide and $67.3 \%-69.1 \%$ amino acid identity [42]. To attain additional sequence information that might be useful in identifying other unique strains, primers designated to amplify other regions of the viral genome e.g. capsid protein region have been evaluated [34, 43 - 49]. The capsid region sequence represents the most variable part of the viral genome. Variation rates among strains of the same genogroup range from $45 \%$ to $61 \%$ and within genotypes at a rate of $14-44 \%$ [20]. In general, highly conserved RNA polymerase sequences are more broadly reactive for norovirus detection than capsid sequences due to lower genetic diversity in that region, but such sequences become problematic for phylogenic classification that cannot correctly separate some strains into proper clusters due to limited sequence variations [47].

\subsubsection{Nested or Semi-Nested RT-PCR}

Nested or semi-nested RT-PCR assays have also been developed to increase the sensitivity and specificity for the detection of norovirus strains in GI and GII [43, 50 - 55]. This approach used two successive runs of PCR employing one (semi-nested) or both (nested) primers in the second round amplification targeting the RNA polymerase or capsid region. This strategy has been reported to achieve at least as sensitive as RT-PCR when used in combination with southern hybridization [54], or 10 to 1000-time more sensitive than single round RT-PCR [51].

\subsubsection{Isothermal Amplification}

Isothermal amplification is sensitive and convenient in amplifying DNA targets, and can be integrated with a RT step for RNA viruses. Isothermal amplification methods such as nucleic acid sequence-based amplification (NASBA) [56 - 60] and RT loop-mediated isothermal amplification (RT-LAMP) [61 - 63] have been developed for norovirus detection. NASBA attained similar analytical detection limits to that of real-time TaqMan RT-PCR assay but provided less consistent signals [59]. Compared to routine RT-PCR, the clinical sensitivity and specificity of the RT-LAMP assay were 100 and $94 \%$ for GI as well as 100 and $100 \%$ for GII, respectively, by analyzing a total of 91 fecal specimens [61].

\subsection{Quantification/Monitoring - RT-qPCR}

Compared to standard RT-PCR in which the product of the reaction is detected at its endpoint, the key feature of real-time quantitative RT-PCR (RT-qPCR) is that the amplicon is detected by continuous measurement of the PCR product as the reaction progresses. This feature eliminates the need for post-amplification processing e.g. agarose gel visualization. Moreover, quantitative determination of target nucleic acid is possible in RT-qPCR assays, although it is not generally used in diagnostics. RT-qPCR commonly utilizes two methods for the detection of noroviruses: 1) nonspecific fluorescent dyes e.g., SYBR green that intercalate with any double-stranded DNA [64 - 67]; and 2) sequencespecific oligonucleotide probes including TaqMan and hybridization probes that are labelled with a fluorescent reporter that enables detection only after specific binding of the probe with its complementary sequence [68 - 79]. SYBR green assay is less costly and simpler than TaqMan assay in its design and manipulation. Direct comparison between SYBR green and TaqMan assay on the detection of noroviruses has not been evaluated. No significant difference between them in terms of specificity, sensitivity and quantitativity in the detection of other pathogen was observed [80]. While the relative conserved viral polymerase region was still favored as the amplification target in many real-time qPCR assays, a GI and GII ORF1-ORF2 junction region, which has been shown the highest sequence similarity across the viral genome, was firstly targeted for the design of primers and TaqMan probes in a norovirus detection assay described by Kageyama and colleagues [68]. Their assay showed a better detection rate in 80 (99\%) of 81 stool samples than conventional RT-PCR assays that detected $77 \%$ for the polymerase and $83 \%$ for the capsid N/S region, respectively, in the same panel of stool specimens. In addition to two-step assays, RT-qPCR also can be performed in one-step format for simultaneous detection and genotyping of noroviruses [69, 70, 75]. One-step RT-qPCR that combines reverse transcription and cDNA amplification into a single reaction decreases the risk of carryover contamination and 
experimental variation since both reactions take place in the same tube, but its following disadvantages are evident: difficult to optimize the two reactions separately; detection of fewer targets per sample; and likely less sensitive than two-step assay since the reaction conditions are a compromise between the two combined reactions. Overall, with improved specificity and sensitivity, and capability of viral load quantitation, RT-qPCR has now been widely used as a reference laboratory approach for detecting norovirus in fecal specimens, water and food [2]. However, its multiplex application which has been limited by the availability of fluorescent reporter dyes is a remained issue.

\subsection{Differentiation/Genotyping - Multiplex Testing, DNA Microarrays, and NGS}

\subsubsection{Multiplex Testing}

Noroviruses, along with other gastrointestinal pathogens, can be detected using multiplex molecular diagnostic technologies. Multiplex molecular technologies offer rapid and simultaneous detection of multiple nucleic acids in high throughput format within a single reaction, greatly cutting down time, labor and cost associated with single reaction detection technologies. Recently, several multiplex nucleic acid approaches such as BioFire FilmArray Gastrointestinal (GI) Panel (Salt Lake City, UT), Luminex xTAG Gastrointestinal Pathogen Panel (GPP) (Toronto, Canada) and Nanosphere Verigene Enteric Pathogens (EP) Test (Northbrook, IL) for the detection of pathogenic enteric pathogens including noroviruses received clearance from U.S. Food and Drug Administration (Table 1). FilmArray GI Panel is designed to detect 22 bacterial, parasitic and viral agents, including norovirus GI/GII. This device can extract and purify all nucleic acids from the samples, and performs a single, large volume, massively multiplex (RT) PCR reaction followed by individual singleplex second-round PCR reactions to detect the first round amplified products. Buss [81] reported $94.5 \%(52 / 55)$ clinical sensitivity and 98.8\% (1483/1501) specificity of norovirus detection in the performance evaluation of FilmArray GI Panel by testing a total of 1,556 stool specimens comparing to the results obatained by polymerase-capsid junction PCR. Khare [82] also demonstrated high ( $>90 \%)$ sensitivity and specificity for norovirus GI/GII in their study using FilmArray GI Panel. In contrast to FilmArray GI Panel, xTAG GPP requires separate extraction and purification of sample nucleic acid prior to amplification and detection. This approach utilizes multiplex RT-PCR using target-specific TAGed primers and biotinylated primers followed by bead hybridization and detection. xTAG GPP is capable to simultaneously detect 3 viral agents including norovirus GI/GII, 9 bacterial, and 3 parasitic pathogens responsible for infectious diarrhea. Clinical performance characteristics of norovirus GI/GII in the xTAG GPP assay has been evaluated in several studies [83 - 87]. In these evaluation studies, it demonstrated that the multiplex nucleic acid assays offer an advantage to identify high percentage of mixed viral-bacterial infections in the clinical specimens. Noroviruses were among the most frequently detected pathogens in mixed infections $[81,82,87]$. As the clinical implication of the viruses and bacteria involved in mixed gastroenteritis infections is not well understood, it creates a challenge for the data interpretation to identify the etiologic role of noroviruses during the course of the gastrointestinal disease.

Table 1. Commercial multiplex testing to detect human noroviruses along with other enteric pathogens.

\begin{tabular}{|c|c|c|c|c|c|}
\hline Company & Platform & Method & $\begin{array}{c}\text { No.of Pathogens } \\
\text { Targeted }\end{array}$ & Turnaround Time (h) & FDA Cleared \\
\hline Biofire Diagnostics & FilmArray GI Panel & Nested RT-PCR & 22 & $1-2$ & + \\
\hline Luminex & xTAG GPP & RT-PCR + Bead hybridization & 15 & $\sim 5$ & + \\
\hline Nanosphere & Verigene EP & RT-PCR + nanoparticle hybridization & 7 & $\sim 2$ & + \\
\hline Seegene & Seeplex Diarrhea-V ACE & RT-PCR + capillary electrophoresis & 5 & $\sim 10$ & - \\
\hline Fast-Track Diagnostics & FTD Viral GE & Real-time RT-PCR & 5 & -6 & - \\
\hline
\end{tabular}

Verigene EP Test is an automated, multiplexed molecular diagnostics that uses PCR followed by hybridization to gold nanoparticles to detect specific gastrointestinal microbial nucleic acid genes associated with 7 pathogenic bacteria and viruses including Campylobacter group, Samonella sepcies, Shigella species, Vibrio group, Yersinia enterocolitica, Norovirus GI/GII and Rotavirus A. Of the three multiplex devices, FilmArray and EP Test are sample-to-result systems offering 1-2 h turnaround time, with minimal hands-on time, while xTAG GPP requires $\sim 5 \mathrm{~h}$ with exclusion of sample processing. Despite the longer turnaround time, xTAG GPP can analyze up to 96 samples in an 8-h shift while FilmArray can only process 1 sample at a time. Vitally, xTAG GPP is an open system in which the amplicons need to be handled, there poses an increased likelihood of cross contamination.

In addition to the three FDA-cleared multiplex approaches, Seeplex Diarrhea-V ACE (Seegene, South Korea) and FTD viral GE (Fast-Track Diagnostics, Luxembourg) are other two commercial systems to detect multiple enteric 
viruses. Seeplex Diarrhea-V ACE is a multiplex RT-PCR system that detects 5 diarrheal pathogens including noroviruses GI/GII [88]. FTD viral GE is a two-tube test system using multiplex real-time PCR for detection of norovirus GI, GII, astrovirus, rotavirus, adenovirus and sapovirus. Liu and colleagues [89] developed a TaqMan Array Card-based method (Life Technologies, Grand Island, NY), a 384-well singleplex real-time PCR format, for simultaneous detection of 19 enteropathogens. The TaqMan Array card showed 100\% (31/31) clinical sensitivity and 96.2\% (75/78) specificity for norovirus GII, compared to laboratory-developed PCR-Luminex assay.

Luminex xMAP is an alternative multiplex PCR method for detection of multiple viral pathogens. Liu [90] developed a Luminex xMAP-based assay for simultaneous detection of seven enteric viruses associated with acute gastroenteritis, yielding $86.67 \%$ sensitivity and $100 \%$ specificity in the detection of noroviruses (GI/GII) from clinical fecal specimens when compared with RT-PCR. The study by Hamza [91] revealed the multiplex xMAP assay could simultaneously detect multiple human enteric viruses including noroviruses from environmental water samples.

\subsubsection{DNA Microarrays}

DNA microarrays have been used for simultaneous detection and genotyping noroviruses as well as other enteric viruses in previous studies [92 - 96]. In these reports, RT-PCR with virus-specific primers has been used to amplify the target nucleic acids prior to microarray hybridization, making them still limited in use due to the substantial genetic diversity of the viruses. We recently reported a novel sequence-independent linear RNA amplification of minute amounts of RNA for microarray-based simultaneous detection and identification of multiple enteric viruses including a GII norovirus [97]. This method offered increased microarray detection accuracy over conventional T7 in vitro transcription amplification. Further evaluation of this system in a small-scale study indicated that various genotypes of noroviruses (GI/GII) were detected in clinical specimens, showing 100\% concordance at genogroup level and $85 \%$ at genotype level with regard to RT-PCR and DNA sequencing [98]. In addition to discerning genotypic information on noroviruses, this platform allowed the detection of co-infection with more than one viral pathogens present in the same sample. The use of this platform does not require PCR amplification and may circumvent the primer selection problem resulting from PCR steps owning to the great genetic diversity of the viruses; yet provides a sufficient level of sensitivity. Microarray detection of random PCR amplified nucleic acids from a range of gastrointestinal viruses including Norwalk virus was recently described [99]. DNA microarrays have proven an important means for discovery in numerous studies. But, given the limitations such as cost, sensitivity, validation, and data interpretation/ management, DNA microarrays are not currently implemented in clinical microbiology laboratories or epidemiological investigations for the study of norovirus infections /outbreaks.

\subsubsection{Next-Generation Sequencing (NGS)}

Large amounts of sequence diversity have been observed across ORF2 in norovirus genome. For reliable genotyping of the virus strains, a sequence determination of the complete major capsid region is recommended [20]. More recently, a dual-nomenclature scheme using both ORF1 and ORF2 sequences has been proposed [23] as intergenotype recombination in the ORF1/ORF2 is common. However, partial nucleotide sequences of ORF1 or ORF2 of the virus genome are also used for genotyping the viruses since sequencing of the full major capsid region is not a routine practice with traditional sequencing approaches. Recent development of high-throughput next-generation sequencing (NGS) technology has the potential to revolutionize our ability to nucleic acid sequencing, providing an unprecedented way to rapidly and deeply sequence the genomes of known or unknown microbial organisms. Utilization of NGS technology for the discovery and characterization of noroviruses have been described in a number of studies [100 - 103]. In addition to virus detection and typing in epidemiology investigations, NGS has been applied for norovirus evolution studies to characterize viral communities and dynamics [104, 105]. NGS has opened new avenues for virus research and diagnostic applications. It is envisaged that the development of NGS in will bring new and more understandings of the molecular virology of norovirus that leads to major diagnosis advances.

\section{CONCLUSION}

Human noroviruses are regarded as the single major cause of acute non-bacterial gastroenteritis and foodborne viral illness worldwide but they cannot be cultivated in vitro, and there are no common laboratory animals available for efficient propagation of the viruses. Over the past decades, noroviruses have avoided public attention for being difficult to detect. Recent molecular methods have made the detection, identification and characterization of noroviruses more sensitive and more accurate than before, and have brought new insights into the etiologies of acute gastroenteritis, but the rapid revolution and widespread reported emergence of novel strains of the viruses create an ongoing challenge to 
the use of molecular techniques to detect the viruses [106]. In addition, given the role that noroviruses play in foodborne and waterborne diseases, research needs to be targeted toward further development, and simplification of these new methods to ensure their broadest applications not only in clinical but also in food and environmental settings.

\section{CONFLICT OF INTEREST}

The authors confirm that this article content has no conflict of interest.

\section{ACKNOWLEDGEMENTS}

The authors thank Michael Kulka for reading the manuscript. The views and opinions expressed here do not necessarily represent the official view of the FDA.

\section{REFERENCES}

[1] Kapikian AZ, Wyatt RG, Dolin R, Thornhill TS, Kalica AR, Chanock RM. Visualization by immune electron microscopy of a 27-nm particle associated with acute infectious nonbacterial gastroenteritis. J Virol 1972; 10(5): 1075-81. [PMID: 4117963]

[2] Glass RI, Parashar UD, Estes MK. Norovirus gastroenteritis. N Engl J Med 2009; 361(18): 1776-85. [http://dx.doi.org/10.1056/NEJMra0804575] [PMID: 19864676]

[3] Noel JS, Fankhauser RL, Ando T, Monroe SS, Glass RI. Identification of a distinct common strain of "Norwalk-like viruses" having a global distribution. J Infect Dis 1999; 179(6): 1334-44. [http://dx.doi.org/10.1086/314783] [PMID: 10228052]

[4] Patel MM, Widdowson MA, Glass RI, Akazawa K, Vinjé J, Parashar UD. Systematic literature review of role of noroviruses in sporadic gastroenteritis. Emerg Infect Dis 2008; 14(8): 1224-31. [http://dx.doi.org/10.3201/eid1408.071114] [PMID: 18680645]

[5] Tate JE, Panozzo CA, Payne DC, et al. Decline and change in seasonality of US rotavirus activity after the introduction of rotavirus vaccine. Pediatrics 2009; 124(2): 465-71. [http://dx.doi.org/10.1542/peds.2008-3528] [PMID: 19581260]

[6] Payne DC, Vinjé J, Szilagyi PG, et al. Norovirus and medically attended gastroenteritis in U.S. children. N Engl J Med 2013; 368(12): 1121-30.

[http://dx.doi.org/10.1056/NEJMsa1206589] [PMID: 23514289]

[7] Bean NH, Griffin PM. Foodborne disease outbreaks in the United States, 1973-1987: pathogens, vehicles, and trends. J Food Prot 1990; 53: 804-17.

[8] Slutsker L, Ries AA, Greene KD, Wells JG, Hutwagner L, Griffin PM. Escherichia coli O157:H7 diarrhea in the United States: clinical and epidemiologic features. Ann Intern Med 1997; 126(7): 505-13.

[http://dx.doi.org/10.7326/0003-4819-126-7-199704010-00002] [PMID: 9092315]

[9] Thorne LG, Goodfellow IG. Norovirus gene expression and replication. J Gen Virol 2014; 95(Pt 2): $278-91$. [http://dx.doi.org/10.1099/vir.0.059634-0] [PMID: 24243731]

[10] Clarke IN, Estes MK, Green KY, et al. Caliciviridae. In: King AM, Carstens EB, Lefkowitz EJ, Eds. Virus taxonomy: Classification and nomenclature of viruses: Ninth report of the international committee on taxonomy of viruses. San Diego: Elsevier 2012; pp. 977-86.

[11] Wyatt RG, Dolin R, Blacklow NR, et al. Comparison of three agents of acute infectious nonbacterial gastroenteritis by cross-challenge in volunteers. J Infect Dis 1974; 129(6): 709-14.

[http://dx.doi.org/10.1093/infdis/129.6.709] [PMID: 4209723]

[12] Okada S, Sekine S, Ando T, et al. Antigenic characterization of small, round-structured viruses by immune electron microscopy. J Clin Microbiol 1990; 28(6): 1244-8.

[PMID: 2380353]

[13] Lewis D, Ando T, Humphrey CD, Monroe SS, Glass RI. Use of solid-phase immune electron microscopy for classification of Norwalk-like viruses into six antigenic groups from 10 outbreaks of gastroenteritis in the United States. J Clin Microbiol 1995; 33(2): 501-4. [PMID: 7714218]

[14] Ando T, Noel JS, Fankhauser RL. Genetic classification of "Norwalk-like viruses. J Infect Dis 2000; 181(Suppl. 2): S336-48. [http://dx.doi.org/10.1086/315589] [PMID: 10804147]

[15] Madore HP, Treanor JJ, Buja R, Dolin R. Antigenic relatedness among the Norwalk-like agents by serum antibody rises. J Med Virol 1990; 32(2): 96-101.

[http://dx.doi.org/10.1002/jmv.1890320206] [PMID: 1704048]

[16] Treanor JJ, Jiang X, Madore HP, Estes MK. Subclass-specific serum antibody responses to recombinant Norwalk virus capsid antigen (rNV) in adults infected with Norwalk, Snow Mountain, or Hawaii virus. J Clin Microbiol 1993; 31(6): 1630-4.

[PMID: 8391025] 
[17] Duizer E, Schwab KJ, Neill FH, Atmar RL, Koopmans MP, Estes MK. Laboratory efforts to cultivate noroviruses. J Gen Virol 2004; 85(Pt 1): $79-87$. [http://dx.doi.org/10.1099/vir.0.19478-0] [PMID: 14718622]

[18] Xi JN, Graham DY, Wang KN, Estes MK. Norwalk virus genome cloning and characterization. Science 1990; $250(4987)$ : 1580-3. [http://dx.doi.org/10.1126/science.2177224] [PMID: 2177224]

[19] Green SM, Dingle KE, Lambden PR, Caul EO, Ashley CR, Clarke IN. Human enteric Caliciviridae: a new prevalent small round-structured virus group defined by RNA-dependent RNA polymerase and capsid diversity. J Gen Virol 1994; 75(Pt 8): $1883-8$. [http://dx.doi.org/10.1099/0022-1317-75-8-1883] [PMID: 8046390]

[20] Zheng DP, Ando T, Fankhauser RL, Beard RS, Glass RI, Monroe SS. Norovirus classification and proposed strain nomenclature. Virology 2006; 346(2): 312-23.

[http://dx.doi.org/10.1016/j.virol.2005.11.015] [PMID: 16343580]

[21] Martella V, Lorusso E, Decaro N, et al. Detection and molecular characterization of a canine norovirus. Emerg Infect Dis 2008; 14(8): 1306-8. [http://dx.doi.org/10.3201/eid1408.080062] [PMID: 18680664]

[22] Tse H, Lau SK, Chan W-M, Choi GK, Woo PC, Yuen K-Y. Complete genome sequences of novel canine noroviruses in Hong Kong. J Virol 2012; 86(17): 9531-2. [http://dx.doi.org/10.1128/JVI.01312-12] [PMID: 22879606]

[23] Kroneman A, Vega E, Vennema H, et al. Proposal for a unified norovirus nomenclature and genotyping. Arch Virol 2013; $158(10)$ : $2059-68$. [http://dx.doi.org/10.1007/s00705-013-1708-5] [PMID: 23615870]

[24] Bull RA, Tanaka MM, White PA. Norovirus recombination. J Gen Virol 2007; 88(Pt 12): 3347-59. [http://dx.doi.org/10.1099/vir.0.83321-0] [PMID: 18024905]

[25] Nayak MK, Balasubramanian G, Sahoo GC, et al. Detection of a novel intergenogroup recombinant Norovirus from Kolkata, India. Virology 2008; 377(1): 117-23. [http://dx.doi.org/10.1016/j.virol.2008.04.027] [PMID: 18555887]

[26] Siebenga JJ, Vennema H, Zheng DP, et al. Norovirus illness is a global problem: emergence and spread of norovirus GII.4 variants, 2001-2007. J Infect Dis 2009; 200(5): 802-12.

[http://dx.doi.org/10.1086/605127] [PMID: 19627248]

[27] Vega E, Barclay L, Gregoricus N, Shirley SH, Lee D, Vinjé J. Genotypic and epidemiologic trends of norovirus outbreaks in the United States, 2009 to 2013. J Clin Microbiol 2014; 52(1): 147-55. [http://dx.doi.org/10.1128/JCM.02680-13] [PMID: 24172151]

[28] Verhoef L, Hewitt J, Barclay L, et al. Norovirus genotype profiles associated with foodborne transmission, 1999-2012. Emerg Infect Dis 2015; 21(4): 592-9. [http://dx.doi.org/10.3201/eid2104.141073] [PMID: 25811368]

[29] Kapikian AZ, Chanock RM. Norwalk group of viruses. In: Fields BN, Knipe DN, Eds. Virology. $2^{\text {nd }}$ ed. New York: Raven Press 1990; pp. 673-93.

[30] Costantini V, Grenz L, Fritzinger A, et al. Diagnostic accuracy and analytical sensitivity of IDEIA Norovirus assay for routine screening of human norovirus. J Clin Microbiol 2010; 48(8): 2770-8. [http://dx.doi.org/10.1128/JCM.00654-10] [PMID: 20554813]

[31] Glass RI, Noel J, Ando T, et al. The epidemiology of enteric caliciviruses from humans: a reassessment using new diagnostics. J Infect Dis 2000; 181(Suppl. 2): S254-61. [http://dx.doi.org/10.1086/315588] [PMID: 10804134]

[32] Lambden PR, Caul EO, Ashley CR, Clarke IN. Sequence and genome organization of a human small round-structured (Norwalk-like) virus. Science 1993; 259(5094): 516-9. [http://dx.doi.org/10.1126/science.8380940] [PMID: 8380940]

[33] Jiang X, Wang J, Graham DY, Estes MK. Detection of Norwalk virus in stool by polymerase chain reaction. J Clin Microbiol 1992; 30(10): 2529-34.

[PMID: 1383265]

[34] De Leon R, Matsui SM, Baric RS, et al. Detection of Norwalk virus in stool specimens by reverse transcriptase-polymerase chain reaction and nonradioactive oligoprobes. J Clin Microbiol 1992; 30(12): 3151-7. [PMID: 1280649]

[35] Green J, Norcott JP, Lewis D, Arnold C, Brown DW. Norwalk-like viruses: demonstration of genomic diversity by polymerase chain reaction. J Clin Microbiol 1993; 31(11): 3007-12. [PMID: 8263187]

[36] Khan AS, Moe CL, Glass RI, et al. Norwalk virus-associated gastroenteritis traced to ice consumption aboard a cruise ship in Hawaii: comparison and application of molecular method-based assays. J Clin Microbiol 1994; 32(2): 318-22.

[PMID: 8150941] 
[37] Moe CL, Gentsch J, Ando T, et al. Application of PCR to detect Norwalk virus in fecal specimens from outbreaks of gastroenteritis. J Clin Microbiol 1994; 32(3): 642-8. [PMID: 8195372]

[38] Ando T, Monroe SS, Gentsch JR, Jin Q, Lewis DC, Glass RI. Detection and differentiation of antigenically distinct small round-structured viruses (Norwalk-like viruses) by reverse transcription-PCR and southern hybridization. J Clin Microbiol 1995; 33(1): 64-71. [PMID: 7699068]

[39] Green J, Gallimore CI, Norcott JP, Lewis D, Brown DW. Broadly reactive reverse transcriptase polymerase chain reaction for the diagnosis of SRSV-associated gastroenteritis. J Med Virol 1995; 47(4): 392-8 [http://dx.doi.org/10.1002/jmv.1890470416] [PMID: 8636708]

[40] Le Guyader F, Neill FH, Estes MK, Monroe SS, Ando T, Atmar RL. Detection and analysis of a small round-structured virus strain in oysters implicated in an outbreak of acute gastroenteritis. Arch Virol 1996; 141: 2225-35. [http://dx.doi.org/10.1007/BF01718228] [PMID: 8973536]

[41] Vinje J, Koopmans PG. Molecular detection and epidemiology of small round-structured viruses in outbreaks of gastroenteritis in the Netherlands. J Infect Dis 1996; 174: 5-610.

[42] Ando T, Mulders MN, Lewis DC, Estes MK, Monroe SS, Glass RI. Comparison of the polymerase region of small round structured virus strains previously characterized in three serotypes by solid phase immune electron microscopy. Arch Virol 1994; 135: $217-26$. [http://dx.doi.org/10.1007/BF01309781] [PMID: 7515226]

[43] Wang J, Jiang X, Madore HP, et al. Sequence diversity of small, round-structured viruses in the Norwalk virus group. J Virol 1994; 68(9): 5982-90.

[PMID: 8057474]

[44] Green SM, Lambden PR, Caul EO, Clarke IN. Capsid sequence diversity in small round structured viruses from recent UK outbreaks of gastroenteritis. J Med Virol 1997; 52(1): 14-9. [http://dx.doi.org/10.1002/(SICI)1096-9071(199705)52:1<14::AID-JMV3>3.0.CO;2-U] [PMID: 9131452]

[45] Häfliger D, Gilgen M, Lüthy J, Hübner P. Seminested RT-PCR systems for small round structured viruses and detection of enteric viruses in seafood. Int J Food Microbiol 1997; 37(1): 27-36. [http://dx.doi.org/10.1016/S0168-1605(97)00041-X] [PMID: 9237119]

[46] Noel JS, Ando T, Leite JP, et al. Correlation of patient immune responses with genetically characterized small round-structured viruses involved in outbreaks of nonbacterial acute gastroenteritis in the United States, 1990 to 1995. J Med Virol 1997; 53(4): $372-83$. [http://dx.doi.org/10.1002/(SICI)1096-9071(199712)53:4<372::AID-JMV10>3.0.CO;2-H] [PMID: 9407386]

[47] Katayama K, Shirato-Horikoshi H, Kojima S, et al. Phylogenetic analysis of the complete genome of 18 Norwalk-like viruses. Virology 2002; 299(2): 225-39. [http://dx.doi.org/10.1006/viro.2002.1568] [PMID: 12202225]

[48] Kojima S, Kageyama T, Fukushi S, et al. Genogroup-specific PCR primers for detection of Norwalk-like viruses. J Virol Methods 2002; 100(1-2): 107-14. [http://dx.doi.org/10.1016/S0166-0934(01)00404-9] [PMID: 11742657]

[49] Vinjé J, Hamidjaja RA, Sobsey MD. Development and application of a capsid VP1 (region D) based reverse transcription PCR assay for genotyping of genogroup I and II noroviruses. J Virol Methods 2004; 116(2): 109-17. [http://dx.doi.org/10.1016/j.jviromet.2003.11.001] [PMID: 14738976]

[50] Stene-Johansen K, Grinde B. Sensitive detection of human Caliciviridae by RT-PCR. J Med Virol 1996; 50(3): $207-13$. [http://dx.doi.org/10.1002/(SICI)1096-9071(199611)50:3<207::AID-JMV1>3.0.CO;2-D] [PMID: 8923284]

[51] Green J, Henshilwood K, Gallimore CI, Brown DW, Lees DN. A nested reverse transcriptase PCR assay for detection of small roundstructured viruses in environmentally contaminated molluscan shellfish. Appl Environ Microbiol 1998; 64(3): 858-63. [PMID: 9501426]

[52] O’Neill HJ, McCaughey C, Wyatt DE, Mitchell F, Coyle PV. Gastroenteritis outbreaks associated with Norwalk-like viruses and their investigation by nested RT-PCR. BMC Microbiol 2001; 1: 14. [http://dx.doi.org/10.1186/1471-2180-1-14] [PMID: 11511325]

[53] Ratcliff RM, Doherty JC, Higgins GD. Sensitive detection of RNA viruses associated with gastroenteritis by a hanging-drop single-tube nested reverse transcription-PCR method. J Clin Microbiol 2002; 40(11): 4091-9. [http://dx.doi.org/10.1128/JCM.40.11.4091-4099.2002] [PMID: 12409380]

[54] Medici MC, Martinelli M, Ruggeri FM, et al. Broadly reactive nested reverse transcription-PCR using an internal RNA standard control for detection of noroviruses in stool samples. J Clin Microbiol 2005; 43(8): 3772-8. [http://dx.doi.org/10.1128/JCM.43.8.3772-3778.2005] [PMID: 16081909]

[55] Shieh Y, Monroe SS, Fankhauser RL, Langlois GW, Burkhardt W III, Baric RS. Detection of norwalk-like virus in shellfish implicated in illness. J Infect Dis 2000; 181(18)(Suppl. 2): S360-6. [http://dx.doi.org/10.1086/315578] [PMID: 10804149]

[56] Greene SR, Moe CL, Jaykus LA, Cronin M, Grosso L, Aarle Pv. Evaluation of the NucliSens Basic Kit assay for detection of Norwalk virus RNA in stool specimens. J Virol Methods 2003; 108(1): 123-31. 
[http://dx.doi.org/10.1016/S0166-0934(02)00286-0] [PMID: 12565163]

[57] Moore C, Clark EM, Gallimore CI, Corden SA, Gray JJ, Westmoreland D. Evaluation of a broadly reactive nucleic acid sequence based amplification assay for the detection of noroviruses in faecal material. J Clin Virol 2004; 29(4): 290-6. [http://dx.doi.org/10.1016/S1386-6532(03)00170-7] [PMID: 15018858]

[58] Patterson SS, Smith MW, Casper ET, et al. A nucleic acid sequence-based amplification assay for real-time detection of norovirus genogroup II. J Appl Microbiol 2006; 101(4): 956-63. [http://dx.doi.org/10.1111/j.1365-2672.2006.02934.x] [PMID: 16968307]

[59] Houde A, Leblanc D, Poitras E, et al. Comparative evaluation of RT-PCR, nucleic acid sequence-based amplification (NASBA) and real-time RT-PCR for detection of noroviruses in faecal material. J Virol Methods 2006; 135(2): 163-72. [http://dx.doi.org/10.1016/j.jviromet.2006.03.001] [PMID: 16616378]

[60] Kou X, Wu Q, Zhang J, Fan H. Rapid detection of noroviruses in fecal samples and shellfish by nucleic acid sequence-based amplification. J Microbiol 2006; 44(4): 403-8.

[PMID: 16953175]

[61] Fukuda S, Takao S, Kuwayama M, Shimazu Y, Miyazaki K. Rapid detection of norovirus from fecal specimens by real-time reverse transcription-loop-mediated isothermal amplification assay. J Clin Microbiol 2006; 44(4): 1376-81. [http://dx.doi.org/10.1128/JCM.44.4.1376-1381.2006] [PMID: 16597865]

[62] Yoda T, Suzuki Y, Yamazaki K, et al. Evaluation and application of reverse transcription loop-mediated isothermal amplification for detection of noroviruses. J Med Virol 2007; 79(3): 326-34. [http://dx.doi.org/10.1002/jmv.20802] [PMID: 17245722]

[63] Iturriza-Gómara M, Xerry J, Gallimore CI, Dockery C, Gray J. Evaluation of the Loopamp (loop-mediated isothermal amplification) kit for detecting Norovirus RNA in faecal samples. J Clin Virol 2008; 42(4): 389-93. [http://dx.doi.org/10.1016/j.jcv.2008.02.012] [PMID: 18394955]

[64] Miller I, Gunson R, Carman WF. Norwalk like virus by light cycler PCR. J Clin Virol 2002; 25(2): $231-2$. [http://dx.doi.org/10.1016/S1386-6532(02)00110-5] [PMID: 12367659]

[65] Richards GP, Watson MA, Kingsley DH. A SYBR green, real-time RT-PCR method to detect and quantitate Norwalk virus in stools. J Virol Methods 2004; 116(1): 63-70. [http://dx.doi.org/10.1016/j.jviromet.2003.10.011] [PMID: 14715308]

[66] Pang X, Lee B, Chui L, Preiksaitis JK, Monroe SS. Evaluation and validation of real-time reverse transcription-pcr assay using the light cycler system for detection and quantitation of norovirus. J Clin Microbiol 2004; 42(10): 4679-85. [http://dx.doi.org/10.1128/JCM.42.10.4679-4685.2004] [PMID: 15472327]

[67] Schmid M, Oehme R, Schalasta G, Brockmann S, Kimmig P, Enders G. Fast detection of Noroviruses using a real-time PCR assay and automated sample preparation. BMC Infect Dis 2004; 4: 15. [http://dx.doi.org/10.1186/1471-2334-4-15] [PMID: 15186502]

[68] Kageyama T, Kojima S, Shinohara M, et al. Broadly reactive and highly sensitive assay for Norwalk-like viruses based on real-time quantitative reverse transcription-PCR. J Clin Microbiol 2003; 41(4): 1548-57. [http://dx.doi.org/10.1128/JCM.41.4.1548-1557.2003] [PMID: 12682144]

[69] Höhne M, Schreier E. Detection and characterization of norovirus outbreaks in Germany: application of a one-tube RT-PCR using a fluorogenic real-time detection system. J Med Virol 2004; 72(2): 312-9. [http://dx.doi.org/10.1002/jmv.10573] [PMID: 14695676]

[70] Jothikumar N, Lowther JA, Henshilwood K, Lees DN, Hill VR, Vinjé J. Rapid and sensitive detection of noroviruses by using TaqMan-based one-step reverse transcription-PCR assays and application to naturally contaminated shellfish samples. Appl Environ Microbiol 2005; 71(4): 1870-5. [http://dx.doi.org/10.1128/AEM.71.4.1870-1875.2005] [PMID: 15812014]

[71] Dreier J, Störmer M, Mäde D, Burkhardt S, Kleesiek K. Enhanced reverse transcription-PCR assay for detection of norovirus genogroup I. J Clin Microbiol 2006; 44(8): 2714-20.

[http://dx.doi.org/10.1128/JCM.00443-06] [PMID: 16891482]

[72] Trujillo AA, McCaustland KA, Zheng DP, et al. Use of TaqMan real-time reverse transcription-PCR for rapid detection, quantification, and typing of norovirus. J Clin Microbiol 2006; 44(4): 1405-12. [http://dx.doi.org/10.1128/JCM.44.4.1405-1412.2006] [PMID: 16597869]

[73] Ishida S, Yoshizumi S, Ikeda T, Miyoshi M, Okano M, Okui T. Sensitive and rapid detection of norovirus using duplex TaqMan reverse transcription-polymerase chain reaction. J Med Virol 2008; 80(5): 913-20. [http://dx.doi.org/10.1002/jmv.21142] [PMID: 18360905]

[74] Logan C, O’Leary JJ, O'Sullivan N. Real-time reverse transcription PCR detection of norovirus, sapovirus and astrovirus as causative agents of acute viral gastroenteritis. J Virol Methods 2007; 146(1-2): 36-44. [http://dx.doi.org/10.1016/j.jviromet.2007.05.031] [PMID: 17644197]

[75] Rolfe KJ, Parmar S, Mururi D, et al. An internally controlled, one-step, real-time RT-PCR assay for norovirus detection and genogrouping. J Clin Virol 2007; 39(4): 318-21. [http://dx.doi.org/10.1016/j.jcv.2007.05.005] [PMID: 17604686] 
[76] Scipioni A, Bourgot I, Mauroy A, et al. Detection and quantification of human and bovine noroviruses by a TaqMan RT-PCR assay with a control for inhibition. Mol Cell Probes 2008; 22(4): 215-22. [http://dx.doi.org/10.1016/j.mcp.2008.02.003] [PMID: 18424068]

[77] Hymas W, Atkinson A, Stevenson J, Hillyard D. Use of modified oligonucleotides to compensate for sequence polymorphisms in the realtime detection of norovirus. J Virol Methods 2007; 142(1-2): 10-4. [http://dx.doi.org/10.1016/j.jviromet.2006.12.009] [PMID: 17222467]

[78] Mohamed N, Belák S, Hedlund KO, Blomberg J. Experience from the development of a diagnostic single tube real-time PCR for human caliciviruses, Norovirus genogroups I and II. J Virol Methods 2006; 132(1-2): 69-76. [http://dx.doi.org/10.1016/j.jviromet.2005.09.006] [PMID: 16289337]

[79] Wolf S, Williamson WM, Hewitt J, et al. Sensitive multiplex real-time reverse transcription-PCR assay for the detection of human and animal noroviruses in clinical and environmental samples. Appl Environ Microbiol 2007; 73(17): 5464-70. [http://dx.doi.org/10.1128/AEM.00572-07] [PMID: 17616614]

[80] Maeda H, Fujimoto C, Haruki Y, et al. Quantitative real-time PCR using TaqMan and SYBR Green for Actinobacillus actinomycetemcomitans, Porphyromonas gingivalis, Prevotella intermedia, tetQ gene and total bacteria. FEMS Immunol Med Microbiol 2003; 39(1): 81-6. [http://dx.doi.org/10.1016/S0928-8244(03)00224-4] [PMID: 14557000]

[81] Buss SN, Leber A, Chapin K, et al. Multicenter evaluation of the BioFire FilmArray gastrointestinal panel for etiologic diagnosis of infectious gastroenteritis. J Clin Microbiol 2015; 53(3): 915-25. [http://dx.doi.org/10.1128/JCM.02674-14] [PMID: 25588652]

[82] Khare R, Espy MJ, Cebelinski E, et al. Comparative evaluation of two commercial multiplex panels for detection of gastrointestinal pathogens by use of clinical stool specimens. J Clin Microbiol 2014; 52(10): 3667-73. [http://dx.doi.org/10.1128/JCM.01637-14] [PMID: 25100818]

[83] Mengelle C, Mansuy JM, Prere MF, et al. Simultaneous detection of gastrointestinal pathogens with a multiplex Luminex-based molecular assay in stool samples from diarrhoeic patients. Clin Microbiol Infect 2013; 19(10): E458-65. [http://dx.doi.org/10.1111/1469-0691.12255] [PMID: 23714194]

[84] Navidad JF, Griswold DJ, Gradus MS, Bhattacharyya S. Evaluation of Luminex xTAG gastrointestinal pathogen analyte-specific reagents for high-throughput, simultaneous detection of bacteria, viruses, and parasites of clinical and public health importance. J Clin Microbiol 2013; 51(9): 3018-24.

[http://dx.doi.org/10.1128/JCM.00896-13] [PMID: 23850948]

[85] Wessels E, Rusman LG, van Bussel MJ, Claas EC. Added value of multiplex Luminex Gastrointestinal Pathogen Panel (xTAG ${ }^{\circledR}$ GPP) testing in the diagnosis of infectious gastroenteritis. Clin Microbiol Infect 2014; 20(3): O182-7. [http://dx.doi.org/10.1111/1469-0691.12364] [PMID: 24131399]

[86] Kahlau P, Malecki M, Schildgen V, et al. Utility of two novel multiplexing assays for the detection of gastrointestinal pathogens - a first experience. Springerplus 2013; 2(1): 106.

[http://dx.doi.org/10.1186/2193-1801-2-106] [PMID: 23544178]

[87] Vocale C, Rimoldi SG, Pagani C, et al. Comparative evaluation of the new xTAG GPP multiplex assay in the laboratory diagnosis of acute gastroenteritis. Clinical assessment and potential application from a multicentre Italian study. Int J Infect Dis 2015; 34 : 33-7. [http://dx.doi.org/10.1016/j.ijid.2015.02.011] [PMID: 25749649]

[88] Higgins RR, Beniprashad M, Cardona M, Masney S, Low DE, Gubbay JB. Evaluation and verification of the Seeplex Diarrhea-V ACE assay for simultaneous detection of adenovirus, rotavirus, and norovirus genogroups I and II in clinical stool specimens. J Clin Microbiol 2011; 49(9): 3154-62.

[http://dx.doi.org/10.1128/JCM.00599-11] [PMID: 21775550]

[89] Liu J, Gratz J, Amour C, et al. A laboratory-developed TaqMan Array Card for simultaneous detection of 19 enteropathogens. J Clin Microbiol 2013; 51(2): 472-80. [http://dx.doi.org/10.1128/JCM.02658-12] [PMID: 23175269]

[90] Liu Y, Xu ZQ, Zhang Q, et al. Simultaneous detection of seven enteric viruses associated with acute gastroenteritis by a multiplexed Luminex-based assay. J Clin Microbiol 2012; 50(7): 2384-9.

[http://dx.doi.org/10.1128/JCM.06790-11] [PMID: 22518865]

[91] Hamza IA, Jurzik L, Wilhelm M. Development of a Luminex assay for the simultaneous detection of human enteric viruses in sewage and river water. J Virol Methods 2014; 204: 65-72. [http://dx.doi.org/10.1016/j.jviromet.2014.04.002] [PMID: 24747587]

[92] Jäskeläinen AJ, Maunula L. Applicability of microarray technique for the detection of noroviruses and astroviruses. J Virol Methods 2006; 136(1-2): 210-6.

[http://dx.doi.org/10.1016/j.jviromet.2006.05.015] [PMID: 16781784]

[93] Pagotto F, Corneau N, Mattison K, Bidawid S. Development of a DNA microarray for the simultaneous detection and genotyping of noroviruses. J Food Prot 2008; 71(7): 1434-41.

[PMID: 18680944] 
[94] Brinkman NE, Fout GS. Development and evaluation of a generic tag array to detect and genotype noroviruses in water. J Virol Methods 2009; 156(1-2): 8-18. [http://dx.doi.org/10.1016/j.jviromet.2008.03.010] [PMID: 18471900]

[95] Chen H, Mammel M, Kulka M, Patel I, Jackson S, Goswami BB. Detection and identification of common food-borne viruses with a tiling microarray. Open Virol J 2011; 5: 52-9. [http://dx.doi.org/10.2174/1874357901105010052] [PMID: 21660190]

[96] Kim JM, Kim SY, Park YB, et al. Simultaneous detection of major enteric viruses using a combimatrix microarray. J Microbiol 2012; 50(6): 970-7.

[http://dx.doi.org/10.1007/s12275-012-2228-9] [PMID: 23104327]

[97] Chen H, Chen X, Hu Y, Yan H. Reproducibility, fidelity, and discriminant validity of linear RNA amplification for microarray-based identification of major human enteric viruses. Appl Microbiol Biotechnol 2013; 97(9): 4129-39. [http://dx.doi.org/10.1007/s00253-013-4769-1] [PMID: 23455564]

[98] Hu Y, Yan H, Mammel M, Chen H. Sequence-independent amplification coupled with DNA microarray analysis for detection and genotyping of noroviruses. AMB Express 2015; 5(1): 69. [http://dx.doi.org/10.1186/s13568-015-0156-x] [PMID: 26556029]

[99] Martínez MA, Soto-Del Río MdeL, Gutiérrez RM, et al. DNA microarray for detection of gastrointestinal viruses. J Clin Microbiol 2015; 53(1): 136-45.

[http://dx.doi.org/10.1128/JCM.01317-14] [PMID: 25355758]

[100] Nakamura S, Yang CS, Sakon N, et al. Direct metagenomic detection of viral pathogens in nasal and fecal specimens using an unbiased highthroughput sequencing approach. PLoS One 2009; 4(1): e4219. [http://dx.doi.org/10.1371/journal.pone.0004219] [PMID: 19156205]

[101] Wong TH, Dearlove BL, Hedge J, et al. Whole genome sequencing and de novo assembly identifies Sydney-like variant noroviruses and recombinants during the winter 2012/2013 outbreak in England. Virol J 2013; 10: 335. [http://dx.doi.org/10.1186/1743-422X-10-335] [PMID: 24220146]

[102] Batty EM, Wong TH, Trebes A, et al. A modified RNA-Seq approach for whole genome sequencing of RNA viruses from faecal and blood samples. PLoS One 2013; 8(6): e66129. [http://dx.doi.org/10.1371/journal.pone.0066129] [PMID: 23762474]

[103] Kundu S, Lockwood J, Depledge DP, et al. Next-generation whole genome sequencing identifies the direction of norovirus transmission in linked patients. Clin Infect Dis 2013; 57(3): 407-14. [http://dx.doi.org/10.1093/cid/cit287] [PMID: 23645848]

[104] Bull RA, Eden JS, Luciani F, McElroy K, Rawlinson WD, White PA. Contribution of intra- and interhost dynamics to norovirus evolution. J Virol 2012; 86(6): 3219-29.

[http://dx.doi.org/10.1128/JVI.06712-11] [PMID: 22205753]

[105] Cotten M, Petrova V, Phan MV, et al. Deep sequencing of norovirus genomes defines evolutionary patterns in an urban tropical setting. J Virol 2014; 88(19): 11056-69. [http://dx.doi.org/10.1128/JVI.01333-14] [PMID: 25056894]

[106] Boon D, Mahar JE, Abente EJ, et al. Comparative evolution of GII.3 and GII.4 norovirus over a 31-year period. J Virol 2011; 85(17): 8656-66. [http://dx.doi.org/10.1128/JVI.00472-11] [PMID: 21715504]

Received: July 13, 2015

Revised: January 11, 2016 Accepted: January 12,2016

(C) Chen and $\mathrm{Hu}$; Licensee Bentham Open.

This is an open access article licensed under the terms of the Creative Commons Attribution-Non-Commercial 4.0 International Public License (CC BY-NC 4.0) (https://creativecommons.org/licenses/by-nc/4.0/legalcode), which permits unrestricted, non-commercial use, distribution and reproduction in any medium, provided the work is properly cited. 